\title{
Gaya Permainan Didiet Violin Dalam Lagu “Turning Point"
}

\author{
Singgih Rastra Kusuma \\ Program Studi Seni Musik, Fakultas Bahasa dan Seni, Universitas Negeri Surabaya \\ Email: singgihraskusuma771@gmail.com
}

\begin{abstract}
Turning Point" Is a song written by Sigit Ardityo or Didiet Violin which was published on January 28, 2018 in "Didiet \& Violin" album. The formulation of research in this study are: 1) How is music arrangement in his song named "Turning Point" by Didiet Violin , 2) What is Didiet's playing style used in song "Turning Point". The method used is descriptive qualitative research. Object of this study is the song "Turning Point", with the focus discussed is the arrangement and His style. Subject of this study named Sigit Ardityo or Didiet Violin. The results of this study focus on arrangements and style on it which includes: 1) In introduction part, there is a melodic variation and fake, then counter melody ends with a transition to connecting to the next section, 2) There are seven differences transitions that exist with each new subdivision move, 3) Has a four times retransition to repeat the same transition, 4) Dissolution as repeater of Theme 1 and Theme 2 by adding melodic variation and fake. So, melody develops in theme, 5) Interlude occurs twice, 6) The melodic codeta found in subdivision M, 7) Coda is part of the dissolution of theme 1,8) Postlude is in subdivision Q, Has successive chord progressions F\#dim-Em, 9) Didiet Violin applies the Classical style, and Jazz in "Turning Point", 10) Use technique of playing like pizzicato, staccato, sautille, glissando, legato, and doublestop to support his playing style, 11) Use Latin genre with Samba pattern, definitely Brazilian Samba.
\end{abstract}

Keywords: Arrangement, Style, “Turning Point” song

\begin{abstract}
Abstrak : Lagu "Turning Point" Merupakan lagu yang ditulis oleh Sigit Ardityo atau Didiet Violin yang dipublikasikan pada tanggal 28 Januari 2018 dalam album "Didiet \& Violin". Rumusan masalah dalam penelitian ini adalah: 1) Bagaimana aransemen dalam lagu "Turning Point" ciptaan Didiet Violin, 2) Bagaimana gaya permainan dalam lagu "Turning Point" ciptaan Didiet Violin. Jenis Penelitian merupakan deskriptif kualitatif. Objek penelitian adalah Lagu "Turning Point", dengan fokus yang dibahas aransemen dan gaya permainan. Subjek penelitian ini adalah Sigit Ardityo atau Didiet Violin. Hasil penelitian ini fokus pada tinjauan aransemen dan gaya permainan yang meliputi : 1) Introduksi yang terdapat melodic variation and fake, kemudian counter melody diakhiri transisi penghubung kebagian selanjutnya, 2) Terdapat tujuh transisi berbeda yang ada setiap perpindahan subbagian baru, 3) empat kali retransisi mengulagi bagian transisi yang sama, 4) Disolusi bertujuan sebagai pengulang dari Tema 1 dan Tema 2 dengan menambahkan melodic variation and fake sehingga tema terjadi pengembangan pada bagian melodinya, 5) Interlude terjadi dua kali, 6) Kodeta melodis terdapat pada subbagian M, 7) Koda merupakan bagian dari disolusi tema 1, 8) Postlude berada pada subbagian q, Memiliki progresi akord secara berturut-turut F\#dim-Em, 9) Didiet Violin menerapkan Gaya (style) Klasik, dan Jazz didalam lagu “Turning Point”, 10) Digunakannya teknik permainan pizzicato, staccato, sautille, glissando, legato, dan doublestop untuk menunjang gaya permainan, 11) Genre yang digunakan merupakan genre Latin dengan Samba pattern, tepatnya Brazilian Samba.
\end{abstract}

Kata Kunci: Aransemen, Gaya Permaninan, Lagu "Turning Point”

\section{PENDAHULUAN}

Perkembangan musik tidak bisa dilepaskan dari perkembangan lain. Contohnya pada perkembangan sosial media. Dalam penyebarannya, sajian musik bisa menjadi sebuah alternatif hiburan selain menonton film ataupun sinetron yang ada di televisi. Seperti contohnya live music yang ada di cafe-cafe yang tersebar di Surabaya dan sekitarnya berlomba-lomba untuk menyajikan tampilan musik guna promosi perdagangan. Selama ini, musik memang bisa didengarkan dan diperdengarkan si semua kalangan usia sehingga pegiat musik akan selalu berinovasi 
sesuai dengan perkembangan jaman yang ada. Di tahun 2020, sebuah music entertainment semakin menjamur mulai dari bergabung dengan Wedding Organizer, Warung Kopi, Pusat Perbelanjaan, hingga acara launcing produk yang kadang tidak ada korelasi yang pasti dengan musik. Belum lagi kita hidup di era yang selalu menggunakan teknologi. Sudah bisa dilihat bahwa media sosial termasuk didalamnya. Instagram, Facebook, Twitter, YouTube sebagai media untuk berkarya serta dapat memperkenalkan diri bahwa seorang individu adalah seorang yang menggeluti bidang musik atau biasa disebut musisi. Begitupun pula Spotify, Joox, iTunes, dan masih banyak situs dan Platformlainnya yang menyediakan fasilitas mendengarkan musik. Sehingga menimbulkan pertanyaan apakah menjadi seorang musisi bisa eksis atau hidup dalam dunianya. Sebagai individu yang harusnya tidak termakan oleh perkembangan, sebaiknya mengembangkan diri sendiri sangat penting, baik softskill maupun hardskill supaya tidak tertinggalkan. Jika sebuah kehidupan bisa ditarik garis merah dengan musik sebagai aktualisasi, musik selalu ada dan tidak bisa dihilangkan, jangan pernah dibayangkan oleh seseorang bahwa musik bisa mempunyai manfaat yang lebih dari negatif, semua aktivitas selayaknya memiliki sisi positif dan negatif sehingga kekhawatiran untuk bermusik tidak harus terlalu terpikirkan.

Sebelum mengenal alat elektronik secanggih abad ke-21, manusia telah menciptakan sebuah sajian musik yang menarik dan memiliki beberapa penamaan dalam instrumen. Mulai dari zaman Barok, sama sekarang pada zaman post modern, musik klasik masih tetap eksis dan diminati oleh manusia bahkan mempelajarinya. Musik klasik dapat disajikan dengan beberapa model, salah satunya dengan format orkes besar atau orkestra. Sebuah orkestra dapat menghimpun beberapa instrumen dari yang berjenis tiup logam, tiup kayu, perkusi, hingga instrumen gesek. Dalam perannya, instrumen gesek merupakan instrumen yang terbanyak dalam jumlah personel dikarenakan untuk menyeimbangkan kekuatan suara dengan instrumen tiup dan perkusif. Instrumen gesek terdiri dari Violin, Viola, Violoncello, Contrabass.

Didalam sebuah tampilan orkestra baik skala kecil maupun besar. Violin merupakan salahsatu intstrumen yang digunakan serta dibutuhkan. Di dalam sebuah orkestra biasanya violin bertindak sebagai lead melody atau melodi utama, sebuah alasan peletakan pada suara satu. Selain itu, violin juga dapat digunakan sebagai instrumen pendamping untuk format combo, sebagai penambah dan pemanis melodi dalam interlude maupun lainnya tergantung alat pendukungnya. Dalam konteks umum, violin sangat mudah dikenali daripada alat musik sejenisnya. Seiring perkembangan jaman, masyarakat khususnya di Indonesia perlahan mengetahui dengan adanya semua informasi yang ada saat melakukan daring di gawai masing-masing. Mulai dari beberapa violinis dunia yang dari beberapa penggolongan zamannya seperti Heinrich Ignaz Franz biber (1644-1704) sampai Antonio Vivaldi (1678-1741) di zaman barok, Leopold Abel Agustus (1717-1794) sampai Giovanni Battista Viotti (1755-1824) di zaman klasik, Jean-Delphin Alard (18151888) sampai Eugene Ysaye (1858-1931) di zaman romantik, kemudian berlanjut hingga menjamur menjari ratusan pemain violin solo dari awal abad 20 sampai abad 21 ini. Beberapa pemain solo biola yang biasanya dikenal umum antaralain, David Oistrakh, Maxim Vengerov, Sarah Chang, Vanessa Mae, dan lainnya. Banyak beberapa musisi solois biola dunia yang sedang happening di tahuntahun belakangan, seperti contohnya Ray Chen, Sumina Studer, Chloe Trevor, David Aaron Carpenter (viola), Two Set Violin (Bratt dan Eddie) dan masih banyak lagi tersebar di seluruh penjuru dunia. Di Indonesia, pemain violin yang paling dikenal untuk pertamakalinya merupakan seorang yang telah menciptakan lagu Kebangsaan Indonesia Raya yaikni W.R. Soepratman atau Wage Rudolf Soepratman. Disamping itu juga ada Idris Sardi, Luluk Purwanto, Henri Lamiri yang sering mengisi Interlude dan menambah manisnya sebuah lagu. Masyarakat melihat pemain-pemain solois biola ini di media siaran televisi sehingga sangat tidak asing bagi pendengar untuk mengetahui gaya permainannya. Salah satu pemain biola di Indonesia dan memiliki ciri khas unik dan permainan yang memiliki gaya tersendiri adalah Didiet Violin.

Sigit Ardityo atau yang biasa dikenal dengan nama panggung Didiet Violin merupakan pemain instrumen biola yang lahir 
pada 22 Mei 1986. Awalnya belajar sejak usia 3 tahun, didampingi dengan kedua orangtuanya yang sama-sama berkecimpung di dunia musik. Didiet adalah Putra dari Joko Wahono, bekerja di Radio Republik Indonesia serta sebagai pengajar di Orkes Simfonia Jakarta dan Sulistyani, seorang pengajar violin serta bekerja di Dinas Pendidikan Nasional sebagai Pegawai Negeri Sipil. Didiet sudah menikah dan dikaruniai seorang anak perempuan. Untuk kali pertama, Didiet tampil di Konser Bunga-bunga Cikini tahun 1992. Sebagai solois, Beliau sering ikut dalam beberapa pagelaran musik yang diadakan oleh beberapa komposer, misalnya dengan Addie MS, Purwatjaraka, Erwin Gutawa, Elfa Secioria, Dwiki Dharmawan, Embong Raharjo. Selain itu, Krisdayanti, 3 Diva, Rossa, Kahitna, Opick, Andien, dan glenn Fredly juga pernah berkolaborasi dengannya.

Pada tahun 2018, tepatnya pada tanggal 28 Januari, Didiet Violin realease album pertamanya yang berjudul "Didiet \& Violin" di platform musik Spotify serta dengan cara penjualan keping CD Album. Lagu-lagu dalam album tersebut antara lain, Just Matter Of Time, Midnight Rain, Adrenaline Rush, Infinity, Kintamani, Stinky Puppet, If Only, dan Turning Point yang digunakan sebagai objek penelitian ini. Sebelum itu, Didiet Violin memperkenalkan lagu-lagunya di Bentara Budaya Jakarta sebagai tajuk 25 tahun berkaryanya. Dengan membawa Didiet Violin Group yang beranggotakan empat orang yang terdiri dari, Indra Prasetyo (gitar), Egy (Piano dan Keyboard), Dion Subiakto (Drum dan Percussion), dan Shadu Rajjidi (Bass). Dalam konser perkenalan tersebut, Didiet mengajak kolaborasi dengan beberapa solois lintas instrumen, seperti halnya Tohpati yang biasanya bermain Gitar, Indro Hardjodikoro seorang bassist, Windy Setiadi bermain Akordion, Yankjay di Gitar serta Noldy B. Pamungkas seorang gitaris yang bekolaborasi dalam lagunya yang berjudul "TurningPoint".

Alasan peneliti memilih subjek seorang violinis bernama Didiet Violin dengan Objek lagu ciptaanya yang berjudul "Turning Point" karena dilihat dari narasumber yang berkompeten di bidang musik sehingga sesuai dengan skripsi peneliti. Kemudian dalam objeknya, lagu tersebut memiliki beberapa peralihan suasana yang tersirat dan tempo yang statis tetapi tetap bisa didengarkan oleh masyarakat umum walaupun sebagai pendengar untuk kali pertama. Bahkan, penelitian ini dilakukan berdasarkan saran lagu dari teman-teman yang merekomendasikan beberapa musik instrumental biola yang sangat cocok untuk dipelajari. Didalam lagu "Turning Point" juga terdapat beberapa unisono atau interlude yang dapat dijadikan referensi bagi pemain biola untuk bermain dan mengisi interlude di lagu-lagu tertentu disamping untuk memunculkan inspirasi solois biola yang mempelajarinya. Juga beberapa alasan seperti terdapat sukat yang berubah sehingga jika mempelajari lagu tersebut diharapkan menambah kepekaan terhadap sebuah sukat saat melakukan sebuah transkripsi atau interpretasi di lagu lainnya dikarenakan beberapa lagu bertajuk instrumental tidak jarang ditemukan perubahan sukat maupun tempo secara mendadak walaupun tidak easylistening. Semua hal tersebut demi meningkatkan kemampuan permainan dengan mengikuti segala perkembangan yang ada. Peneliti juga ingin memperkenalkan sebuah identifikasi lagu dengan ilmiah melalui skripsi yang dibuat oleh peneliti sehingga untuk validitas data sudah tidak diragukan lagi. Bersama itu, seorang Didiet memiliki pribadi yang mudah memberikan ilmu, humoris, serta dapat mengetahui beberapa teknik dan teori musik sehingga karya yang dibuat bisa dipertanggungjawabkan sendiri. Dengan genre khas Didiet Violin, ada Pop, Country, Jazz, masih dipadukan lagi dengan Fusion, Elektronik, Latin dan Rock ditambah beberapa Pizzicato, Glissando, Doublestop terutama di dalam lagu "Turning Point" membuat seorang Didiet memiliki keunggulan tersendiri dan bisa dikatakan sebagai sebuah gaya permainan individu seorang Didiet yang bisa didengar di semua lagu-lagunya atau pembeda atau lain daripada yang lain. Ditambah lagi dengan inspirasi bermusiknya dari Secret Garden, Didier Lockwood, Karen Briggs, dan lainnya yang membuat sebuah karakter melalui interpretasi lagu menjadi sesuai khas Didiet.

\section{METODE}

Penelitian dengan judul Gaya Permainan Didiet Violin dalam lagu "Turning Point" meninjau tentang Gaya Permainan dan Bentuk Musik menggunakan pendekatan penelitian kualitatif. Subjek penelitian merupakan seorang Solois Biola yang bernama Sigit Ardityo atau yang biasa dikenal dengan 
nama Didiet Violin. Objek penelitian merupakan sebuah lagu ciptaan Didiet yang berjudul "TurningPoint". Lokasi yang digunakan dalam penelitian ini adalah Rumah Kediaman Didiet Violin. Beberapa wawancara akan dilakukan via WhatsApp dan lewat komunikasi secara jarak jauh atau via telepon. Teknik Pengumpulan data pada penelitian ini meliputi observasi, wawancara, dokumentasi.

Observasi adalah salah satu teknik pengumpulan data yang dilakukan melalui proses pengamatan dan pencatatan suatu obyek dengan sistematika fenomena yang diselidiki. Setelah itu, observasi dibedakan menjadi dua yaitu, Observasi Berperan Serta (Participant observation), dan Observasi tak berperan serta (nonparticipant observation) (Sugiyono, 2015). Dalam penelitian ini,peneliti melakukan observasi tak berperan serta karena segala data yang didapat bersumber dari pribadi narasumber.

Wawancara adalah teknik penelitian yang dilaksanakan dengan cara dialog baik secara langsung (tatap muka) maupun melalui saluran media tertentu antara pewawancara dengan narasumber sebagai sumber data (Sanjaya, 2013). Pada penelitian ini menggunakan jenis wawancara secara terstruktur dan wawancara tidak terstruktur. Wawancara terstruktur adalah wawancara dengan pertanyaan yang sudah disiapkan oleh peneliti sebelum peneliti melakukan kegiatan wawancara. Wawancara tak terstruktur adalah wawancara yang bebas dimana peneliti tidak menggunakan pedoman wawancara yang tersusun sistematis dan lengkap sebagai pengumpulan data seperti wawancara terstruktur (Sugiyono, 2012). Untuk penelitian ini, wawancara dilakukan sesuai dengan rencana pertanyaan yang sudah disusun sebelum bertemu dengan narasumber dengan kata lain wawancara yang digunakan bersifat terstruktur, walaupun pada saat pelaksanaannya, peneliti juga menanyakan hal diluar pertanyaan yang sudah disusun bisa jadi disebabkan susunan pertanyaan yang belum dicantumkan dalam susunan pertanyaan prawawancara.

Dokumentasi merupakan suatu urutan cara mengumpulan data melalui catatancatatan, dokumen atau rekam jejak, baik bersumber dari Narasumber, maupun melakukan secara langsung saat proses pengambilan data. Dengan hal ini, peneliti mencari data dokumentasi melalui sebuah dokumen yang dimiliki Didiet Violin berupatranskripsi repertoar lagu atau profilnya.

Validitas data merupakan keabsahan, keakuratan, dan kebenaran data yang dilakukan diawal penelitian dilakukan yang nantinya akan membawa hasil penelitian yang tepat dan valid sesuai dengan konteks supaya tidak adanya pelebaran suatu kajian atau tinjauan. Penulis menggunakan triangulasi sebagai teknik dalam pengumpulan data. Triangulasi merupakan saalah satu teknik dalam mengumpulkan sebuah data yang lebih akurat serta kredibel. Penelitian ini menggunakan triangulasi sumber yang berarti memvalidasi sebuah kajian kepada narasumber sebagai sumber informasi yang tepat. Digunakan metode ini agar Didiet Violin dapat memberikan informasi melalui wawancara atau datanya secara detail dan menyeluruh kemudian hasilnya dapat dipastikan valid.

Teknik Analisis data dalam penelitian ini mengunakan tiga komponen yang dijelaskan oleh Bogdan dalam (Sugiyono, 2005) yang menjabarkan tentang pengertian analisis data sebagai proses mencari dan menyusun data secara sistematis. Cara tersebut yakni reduksi data, penyajian data, dan penyimpulan.

Reduksi data termasuk dalam pengerjaan analisis data. Data yang diperoleh di lapangan beraneka ragamnya, bisa berupa foto, audio, dan hasil wawancara. Pada tahapan tersebut peneliti sangat butuh dan perlu melakukan pemilihan data yang sudah pasti dianggap relevan sesuai dengan yang diinginkan sehingga data yang kita peroleh dapat mendukung penelitian yang dilakukan dengan menggunakan pengkodean tertentu supaya mudah dipahami

Penyimpulan (verification) merupakan langkah selanjutnya yang dilakukan peneliti setelah data tersaji secara sistematis dan terperinci dengan melakukan aktivitas penarikan kesimpulan dan verifikasi data. Kegiatan yang lebih dikhususkan pada sebuah dan beberapa penafsiran data yang telah disajikan, dari data yang terinterpretasikan dan teruraikan lalu ditarik kesimpulan yang sesuai dengan kajian peneliti.

\section{HASIL DAN PEMBAHASAN}

\section{Lagu "Turning Point"}

Lagu "Turning Point" merupakan lagu

satu bagian, terdiri dari 141 birama. 
Aransemen yang terdapat pada lagu "Turning Point" merupakan aransemen instrumen dimana aransemen hanya terdiri dan dimainkan oleh beberapa instrumen tanpa vokal sedikitpun, yang ada dan bertindak sebagai melodi utama adalah violin. Didiet Violin merupakan pemain violin dalam lagu ini dengan didampingi pemain combo, meliputi Gitar, Bass, Keyboard, Drum, Konga, Maraccas. Terdapat beberapa pembagian instrumentasi. Terdapat tiga jenis gitar yang digunakan, meliputi Nylon, Steel-Strings, dan Electric. Pada instrumen bass, bass yang digunakan terdapat dua macam, yakni 5strings bass dan 6-strings bass yang direkam pada bagian tertentu. Keyboard yang masih dibagi beberapa suara, bertindak sebagai suara Glockenspiel, dan juga sebagai piano itu sendiri. Pada violin, Didiet menggunakan 5strings Violin. Lagu "Turning Point" merupakan lagu yang paling kaya secara instrumen yang terdapat didalam album "Didiet \& Violin.

Apabila diterjemahkan, "Turning Point" dalam Bahasa Indonesia berarti titik balik, kembali ke nol. Sebelum menciptakan lagu ini, Didiet mengalami beberapa permasalahan kehidupan dari masalah percintaan, tidak adanya pekerjaan, sampai permasalahan keuangan yang membuat dirinya sempat down. Dengan terciptanya lagu "Turning Point", Didiet menunjukkan bahwa dirinya happy, mengungkapkan selebrasi bahwa sudah melewati masa-masa itu tanpa melupakan apa yang sudah terjadi. Jadi makna dari lagu "Turning Point" merupakan apa yang dialami oleh Didiet Violin secara pribadi dalam kehidupannya.

\section{Aransemen}

Pada Lagu "Turning Point" terdapat struktur serta penjelasan didalamnya. Berdasarkan penelitian yang dilakukan guna mendeskripsikan aransemen lagu tersebut, peneliti membagi bagian dari 141 birama menjadi 17 subbagian, meliputi:

\section{Subbagian a}

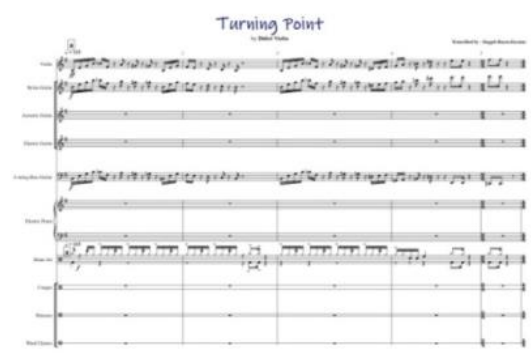

Gambar 1. Subbagian a

Subbagian a pada lagu "Turning Point"diatas terdiri dari 5 birama serta tanda birama 4/4 dan 2/4. Pada birama 1 sampai birama 4 merupakan rangkaian introduksi dari lagu ini karena karena terletak sebelum tema dimainkan dan terletak pada awal lagu. Memiliki progresi akord secara berturut-turut Em-Am-B-Em-Am-Em-B. pada birama $3 \mathrm{ke}$ birama 4 terdapat melodic variation and fake didalamnya karena pada ketukan empat birama 3 sampai berakhirnya birama 4 merupakan pengembangan melodi sebelumnya, dengan menyisipkan nada lain tetapi tetap dengan ritmis yang sama serta dimainkan violin, gitar, bass. Hal yang sudah dibahas dapat dilihat pada notasi berikut.

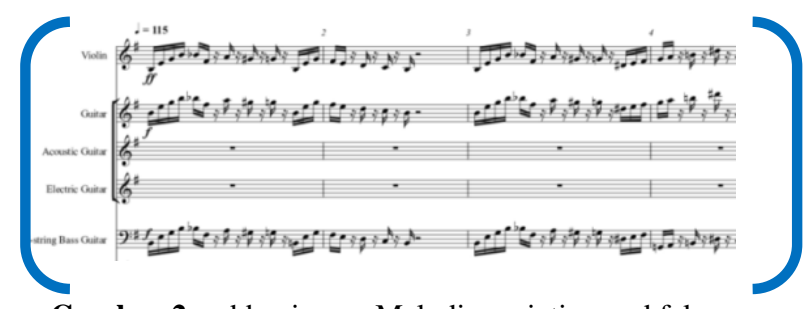

Gambar 2. subbagian a : Melodic variation and fake

Selain itu, terdapat transisi singkat atau bridge yang ditandai dengan tanda birama 2/4 serta dimainkan oleh violin, gitar, bass, dan drum. Hal tersebut dapat terlihat jelas pada notasi berikut.

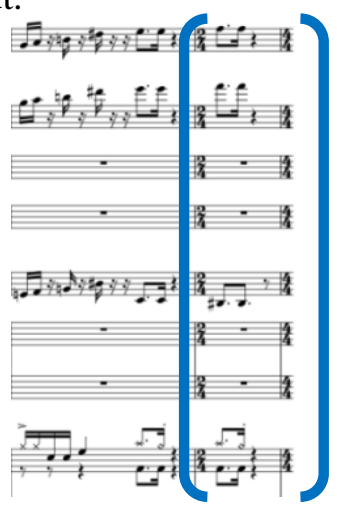

Gambar 3 subbagian a : transisi singkat atau bridge 


\section{Subbagian b}

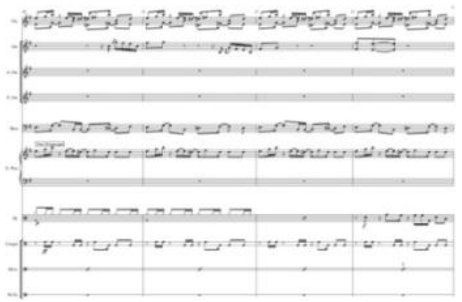

Gambar 4. subbagian b.1

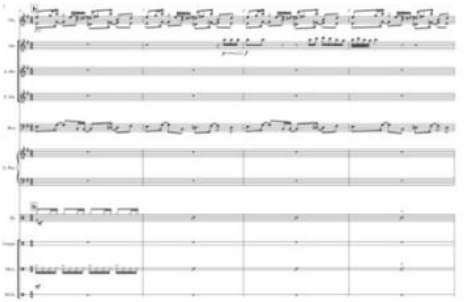

Gambar 5. subbagian b.2

Subbagian b pada lagu "Turning Point" diatas terdiri dari 8 birama serta tanda birama 4/4. Pada birama 6 sampai birama 13 merupakan serangkaian introduksi dari lagu ini karena terletak sebelum tema dimainkan dan terletak pada awal lagu. Memiliki progresi akord secara berturut-turut Em sampai berakhirnya subbagian b. pada instrumem violin, dibagi menjadi dua layer pada satu garis birama sebagai counter melody. Dapat dilihat pada notasi dibawah.

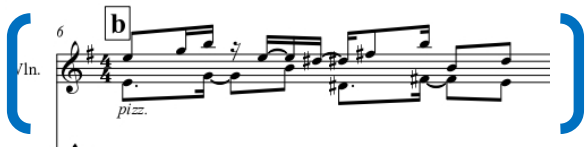

Gambar 6. Subbagian b: counter melodi

Kemudian, pada ketukan keempat birama 7 sampai birama 9 ketukan kedua, birama 10 sampai birama 12 dan birama 13 instrumen gitar terdapat obbligato untuk mengisi

kosongnya,melodi utama berperan sebagai mel odi sekunder saat melodi yang utama melakukan sekuen secara konstan tanpa merubah pola melodi hingga akhir subbagian b. Hal tersebut dapat dilihat pada notasi berikut.

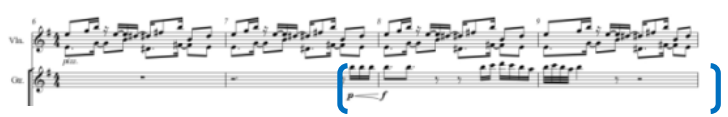

Gambar 7. Subbagian b : obbligato

Instrumen bass dan piano memainkan pola ritmis dan melodis berbeda masingmasing bertindak sebagai counter melodi dari bagian ini. Hal tersebut dapat dilihat pada notasi berikut.

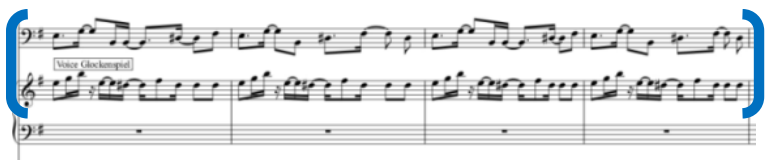

Gambar 8. Subbagian b : counter melodi

Pada birama 13 ketukan keempat, instrumen drum melakukan transisi singkat atau bridge sebagai penghubung antara introduksi dengan tema utama pada lagu "Turning Point".

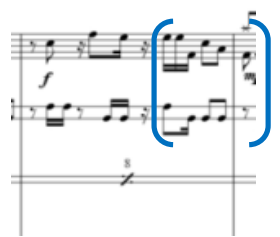

Gambar 9. Subbagian B : transisi singkat atau brigde Subbagian c

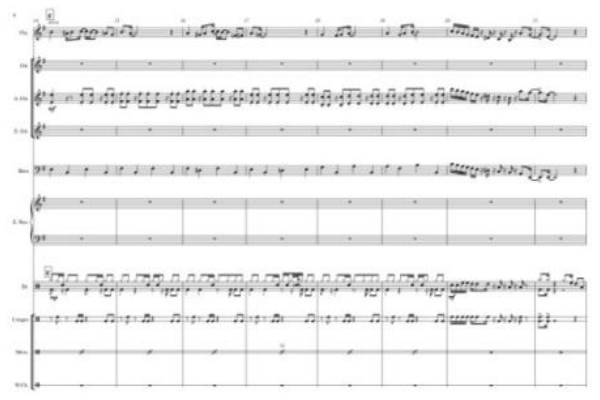

Gambar 10 Subbagian c

Subbagian c pada lagu "Turning Point" diatas terdiri dari 8 birama serta tanda birama 4/4. Pada birama 14 sampai birama 21 merupakan serangkaian seksi dari lagu ini karena terdapat tema utama sebagai inti dari lagu "Turning Point". Memiliki progresi akord secara berturut-turut Em-F\#dim-Am-Em-C-DBm-Em-Am-B-Em. Pada instrumen drum, birama 21 ketukan ketiga merupakan transisi singkat atau bridge yang berbeda dari sebelumnya sebagai penghubung antara tema utama dengan disolusi tema berikutnya. Seperti contoh notasi dibawah ini.

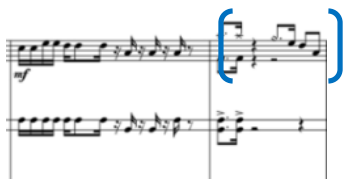

Gambar 11. Subbagian c : tansisi singkat atau bridge 


\section{Subbagian d}

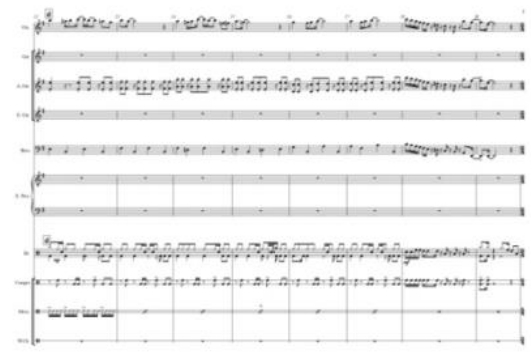

Gambar 12. Subbagian d

Subbagian d pada lagu "Turning Point" diatas terdiri dari 8 birama serta tanda birama 4/4. Pada birama 22 sampai birama 29 merupakan disolusi dari lagu ini karena bagian tersebut dinaikkan 1 oktaf lebih tinggi tanpa merubah pola melodi dan ritmis serta terletak sesudah tema pertama dipisahkan dengan transisi. Memiliki progresi akord secara berturut-turut Em-F\#dim-Am-Em-C-D-BmEm-Am-B-Em. Pada subbagian d birama 29 ketukan ketiga terjadi retransisi antisipatif atau anticipatory transition pada instrumen drum dari tema utama sebelumnya.

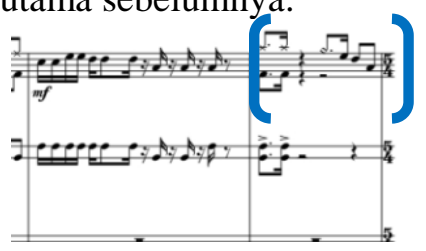

Gambar 13. Subbagian d : retransisi antisipatif atau anticipatory transition

\section{Subbagian e}

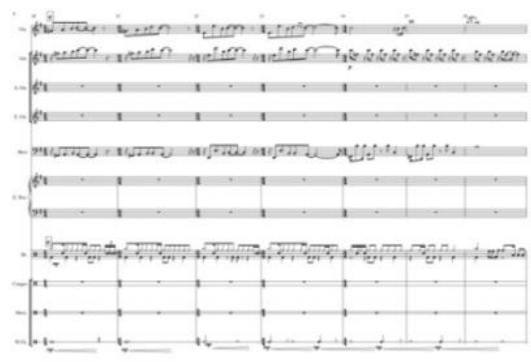

Gambar 14 Subbagian e

Subbagian e pada lagu "Turning Point" diatas terdiri dari 7 birama serta tanda birama secara berturut-turut 5/4,6/4, 5/4,6/4, kemudian kembali ke 4/4. Pada birama 30 sampai birama 36 merupakan tema kedua dari lagu ini karena alurnya berjalan mengikuti tema awal, hanyasaja memiliki perbedaan sukat atau tanda birama yang bervariasi. Memiliki progresi akord secara berturut-turut E-Am sebanyak empat kali, kemudian dilanjutkan $\mathrm{F}$ dan $\mathrm{B}$. pada bagian ini, instrumen gitar dan bass melakukan rythmic variation and fake dengan memberi selisih 1/32 ketuk lebih lambat dari violin sebagai pemegang melodi utama. Instrumen bass didalamnya melakukan counter melodi terhadap violin dan gitar yang pola melodinya sama sebagai pengisi garis harmoni melodi utama tetapi tetap mengikuti selisih ketukan yang terjadi di instrumen gitar hingga birama 33 sebelum terjadi perpindahan tanda birama menjadi 4/4.

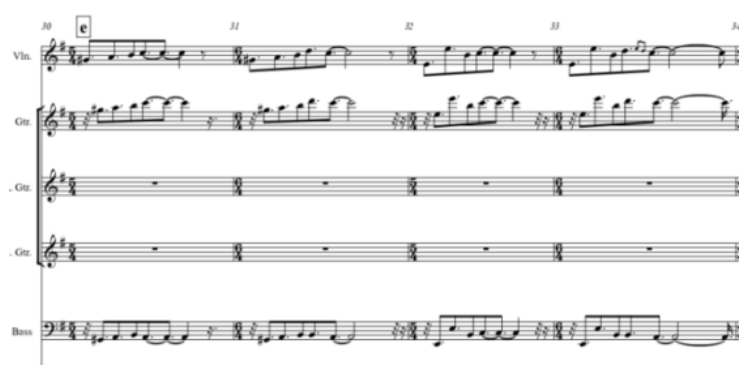

Gambar 15. subbagian e : rythmic variation and fake Pada instrumen drum, birama 36 merupakan transisi singkat atau bridge yang berbeda dari sebelumnya sebagai penghubung antara tema kedua dengan disolusi tema utama. Seperti pada contoh berikut.

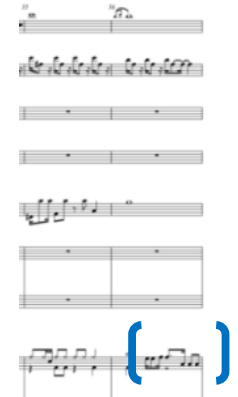

Gambar 16. Subbagian e : transisi singkat atau bridge Subbagian f

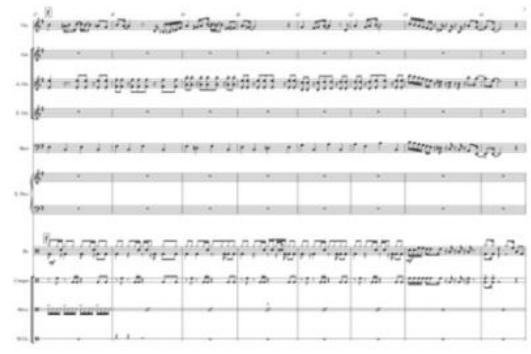

Gambar 17. Subbagian $\mathrm{f}$

Subbagian f pada lagu "Turning Point" diatas terdiri dari 8 birama serta tanda birama 4/4. Pada birama 37 sampai birama 44 merupakan disolusi yang kedua dari tema utama atau pertama lagu ini karena mengulang tema awal dan menambahkan beberapa variasi melodi serta ada setelah disolusi yang pertama antara birama 22 sampai birama 29. Memiliki 
progresi akord secara berturut-turut EmF\#dim-Am-Em-C-D-Bm-Em-Am-B-Em. Pada birama 38 terjadi variasi tema yang dikembangkan yang bisa dikatakan variasi melodi pada subbagian ini berdasarkan tema utama diawal begitu juga dengan birama antara birama 41 dengan birama 42 yang terdapat melodic variation and fake. Hal tersebut dapat dilihat pada notasi berikut.

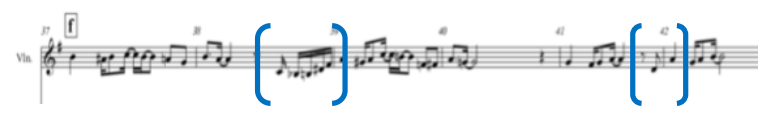

Gambar 18. Subbagian $\mathrm{f}$ : melodic variation and fake Pada birama 44 ketukan ketiga terjadi retransisi antisipatif atau anticipatory transition pada instrumen drum seperti pada birama 29 dengan pola ritmis yang sama. Contoh :

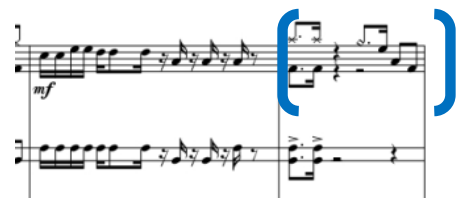

Gambar 19. Subbagian $f$ : retransisi antisipatif atau anticipatory transition

\section{Subbagian g}

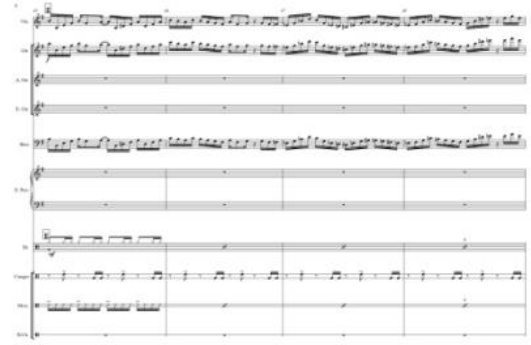

Gambar 20. Subbagian g.1

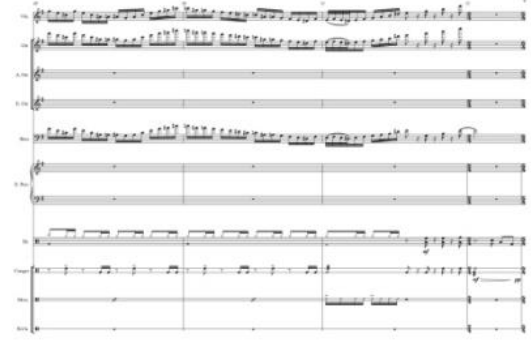

Gambar 21. Subbagian g.2

Subbagian g pada lagu "Turning Point" diatas terdiri dari 8 birama serta tanda birama 4/4 dan 2/4. Pada birama 45 sampai birama 52 merupakan interlude yang pertama dari lagu ini karena sifatnya berdiri sendiri diantara disolusi tema pertama dan diikuti tema kedua setelahnya. Memiliki progresi akord secara berturut-turut Em-B-Em-EbEdim-B-Em-Edim-B-Em. Pada subbagian ini, instrumen violin, gitar, dan bass memainkan melodi bersamaan kemudian terjadinya perubahan ritmis terhadap drum dan maraccas. Hal tersebut dapat dilihat pada notasi berikut.

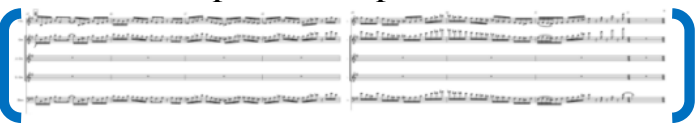

Gambar 22. Subbagian $g$ : tutti

Pada instrumen drum dan congas, birama 51 sampai perubahan tanda birama ke 2/4 di birama 52 merupakan transisi singkat atau bridge yang berbeda dari sebelumnya sebagai penghubung antara interlude dengan repetisi tema kedua. Hal tersebut dapat dilihat pada notasi berikut.

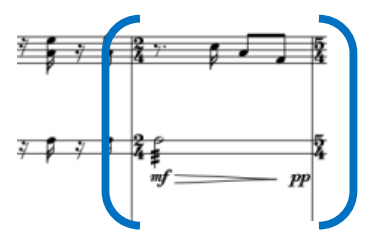

Gambar 23. Subbagian $g$ : transisi singkat atau bridge Subbagian h

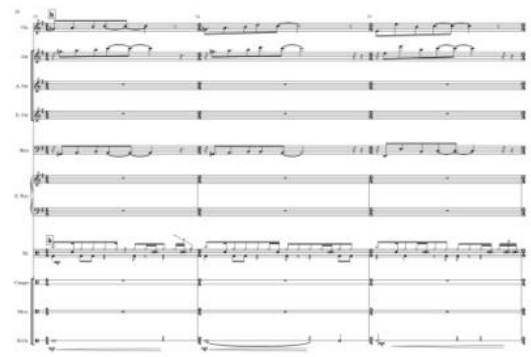

Gambar 24. Subbagian h.1

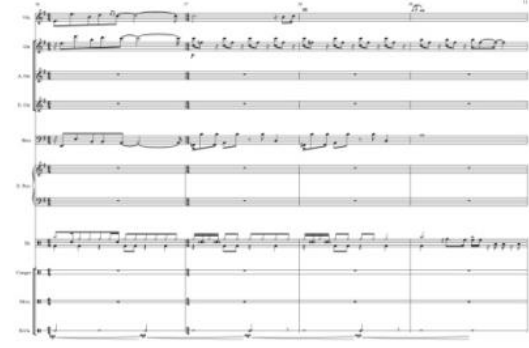

Gambar 25. subbagian h.2

Subbagian h pada lagu "Turning Point" diatas terdiri dari 7 birama serta tanda birama secara berturut-turut 5/4,6/4, 5/4,6/4, kemudian kembali ke 4/4. Pada birama 53 sampai birama 59 merupakan merupakan repetisi tema kedua dari lagu ini karena mengulang subbagian e, tetapi memiliki transisi yang berbeda diakhir pada ritmis drum. Memiliki progresi akord secara berturutturut E-Am sebanyak empat kali, kemudian F 
dan B. Sama seperti subbagian e, instrumen gitar dan bass melakukan rythmic variation and fake dengan memberi selisih 1/32 ketuk lebih lambat dari violin sebagai pemegang melodi utama. Instrumen bass didalamnya melakukan counter melodi terhadap violin dan gitar yang pola melodinya sama sebagai pengisi garis harmoni melodi utama tetapi tetap mengikuti selisih ketukan yang terjadi di instrumen gitar hingga birama 56 sebelum terjadi perpindahan tanda birama menjadi 4/4.
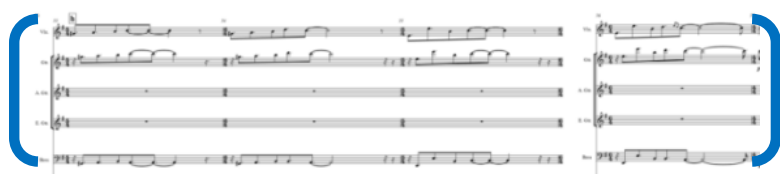

Gambar 26. Subbagian $\mathrm{h}$ : rythmic variation and fake Pada instrumen drum, birama 59 merupakan transisi singkat atau bridge yang berbeda dari sebelumnya sebagai penghubung antara repetisi tema kedua dengan disolusi tema utama. Hal tersebut dapat dilihat pada notasi berikut.

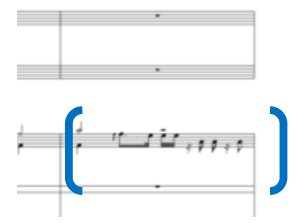

Gambar 27. Subbagian $\mathrm{h}$ : transisi singkat atau bridge Subbagian i

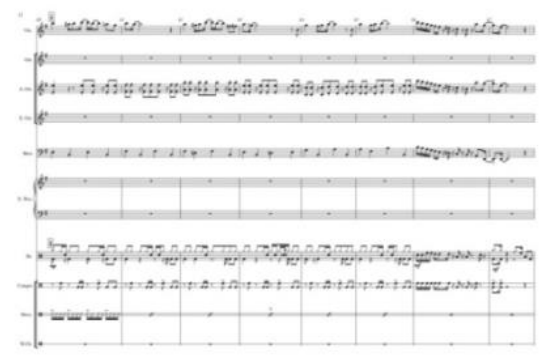

Gambar 28. Subbagian i

Subbagian i pada lagu "Turning Point" diatas terdiri dari 8 birama serta tanda birama 4/4. Pada birama 60 sampai birama 67 merupakan disolusi yang ketiga dari lagu ini karena mengulang disolusi tema awal dan menambahkan beberapa variasi melodi serta ada setelah disolusi yang kedua antara birama 22 sampai birama 29. Memiliki progresi akord secara berturut-turut Em-F\#dim-Am-Em-C-DBm-Em-Am-B-Em. Pada birama 63 sampai birama 65 terjadi variasi tema yang dikembangkan yang bisa dikatakan melodic variation and fake pada subbagian ini berdasarkan disolusi tema utama. Hal tersebut dapat dilihat pada notasi berikut.

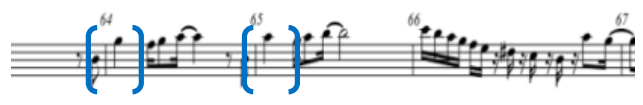

Gambar 29. Subbagian i : melodic variation and fake

Pada birama 67 ketukan ketiga terjadi retransisi antisipatif atau anticipatory transition pada instrumen drum seperti pada birama 29 dan 44 dengan pola ritmikal yang sama. Terlihat seperti pada contoh gambar subbagian i dibawah.

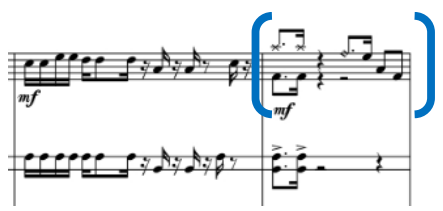

Gambar 30. Subbagian i : retransisi antisipatif atau anticipatory transition

\section{Subbagian $\mathbf{j}$}

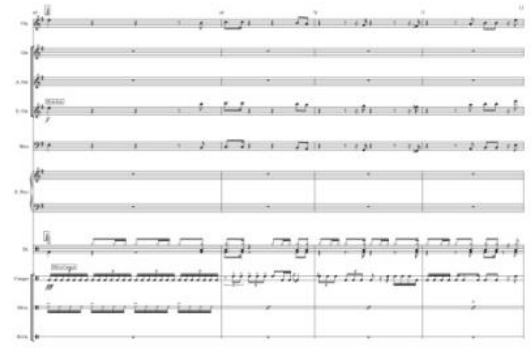

Gambar 31. Subbagian j.1

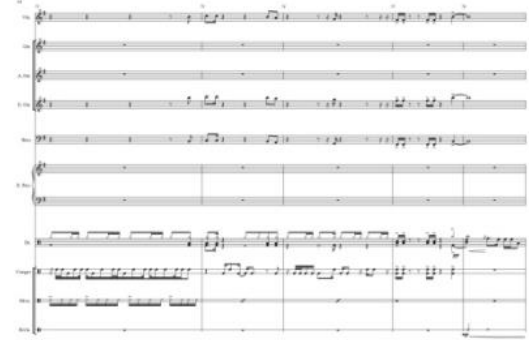

Gambar 32. Subbagian j.2

Subbagian j pada lagu "Turning Point" diatas terdiri dari 9 birama serta tanda birama 4/4. Pada birama 68 sampai 76 merupakan interlude kedua dari lagu ini karena terletak sesudah interlude pertama. Memiliki progresi akord secara berturut-turut Em-Am-G-F-BEm-Am-G-F\#dim-B. subbagian ini merupakan grande. Pada instrumen violin, gitar, bass, memainkan pola ritmis dan melodi yang sama dan bass dari drum memainkan pola ritmis mengikuti tiga instrumen tersebut. Pada interlude di subbagian ini, congas bertindak sebagai filler like obbligato mengisi kekosongan melodi utama sampai berakhirnya 
subbagian $\mathrm{j}$ ini. Hal tersebut dapat dilihat pada notasi berikut.

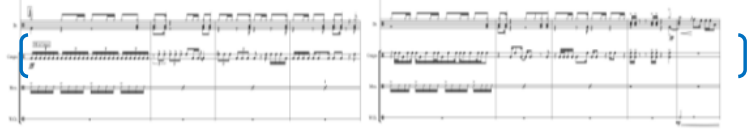

Gambar 33. Subbagian $\mathrm{j}$ : filler like obbligato

\section{Subbagian $k$}

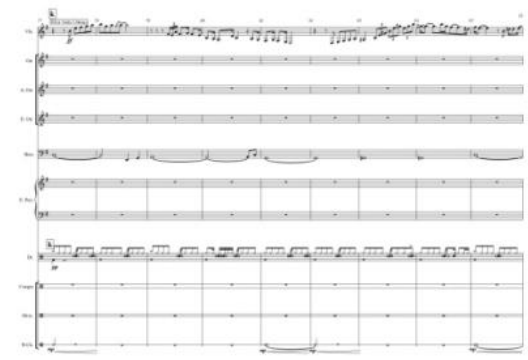

Gambar 34. Subbagian k.1

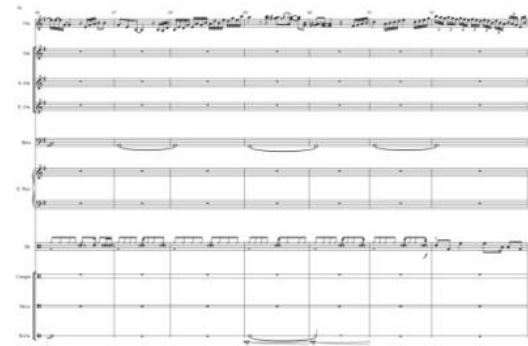

Gambar 35. Subbagian k.2

Subbagian $\mathrm{k}$ pada lagu "Turning Point" diatas terdiri dari 16 birama serta tanda birama 4/4. Pada birama 77 sampai 92 merupakan interlude yang ketiga dimainkan oleh melodi utama, yakni violin. Memiliki progresi akord secara berturut-turut C-Am-GE-Em-C-Am-G-Am-B. Pada Subbagian k, instrumen violin hanya diiringi bass, hi-hat drum dan wind chimes dengan ritmis yang sederhana. Bass melakukan counter melodi terhadap violin sebagai garis harmoni yang mendukungnya.

\section{Subbagian 1}

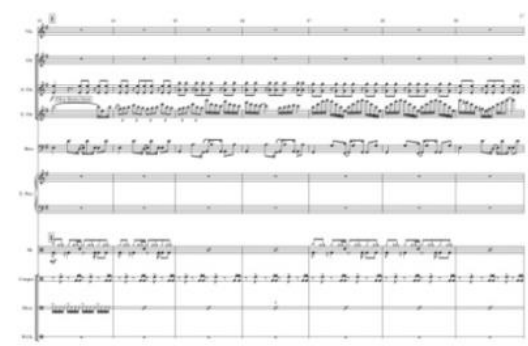

Gambar 36. subbagian 1.1

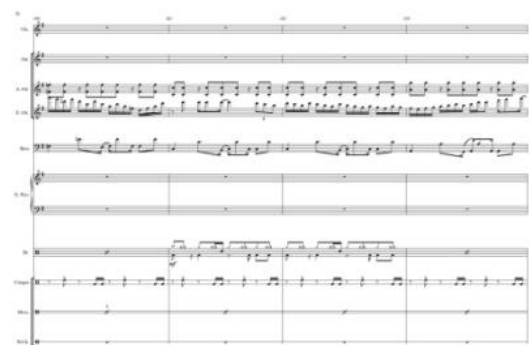

Gambar 37. Subbagian 1.2

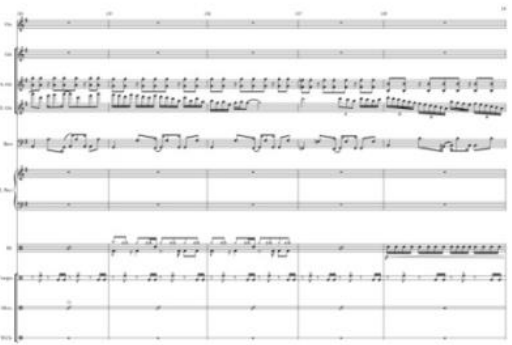

Gambar 38. Subbagian 1.3

Subbagian k pada lagu "Turning Point" diatas terdiri dari 16 birama serta tanda birama 4/4. Pada birama 93 sampai 108 merupakan interlude yang keempat dimainkan oleh electric guitar berurutan setelah violin mengisi interlude yang ketiga. Memiliki progresi akord secara berturut-turut Em-AmG-E-F-C-Am-G-F-B. Pada instrumen drum pola ritmisnya sama dengan mengiringi tema utama. Pada instrumen gitar, pola ritmisnya sama hanyasaja progresi akord yang berbeda. Electric guitar melakukan filler like obbligato sebagai pengisi kekosongan instrumen utama sebagai melodi utama.

\section{Subbagian m}

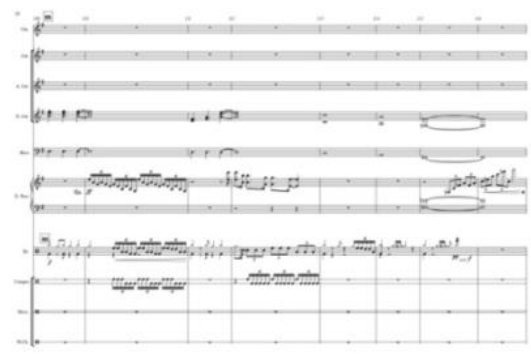

Gambar 39. Subbagian $m$

Subbagian $m$ pada lagu "Turning Point" diatas terdiri dari 8 birama serta tanda birama 4/4. Pada birama 109 sampai 116 merupakan kodeta dari lagu ini karena tidak ada unsur tema didalamnya berarti berdiri sendiri sebagai koda kecil sebelum kembali ke tema. Memiliki progresi akord secara berturutturut Em-D-C-Am-F. Instrumen piano bertindak sebagai filler like obbligato mengisi kekosongan pada melodi utama, yakni melodi 
violin. Hal tersebut dapat dilihat pada notasi berikut.

(

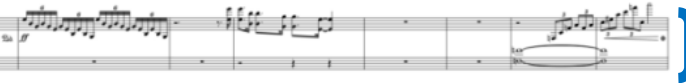

Gambar 40. Subbagian $m$ : filler like obbligato Pada instrumen drum dan congas di birama 110 ketukan kedua, menyamakan ritmis dengan piano yang memainkan sixtuplet. Hal tersebut dapat dilihat pada notasi berikut.

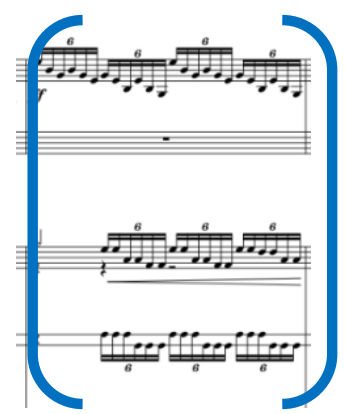

Gambar 41. subbagian $m$ : Sixtuplet piano, drum congas Subbagian n

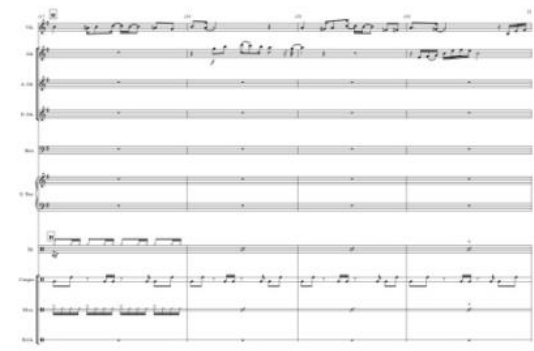

Gambar 42. Subbagian n.1

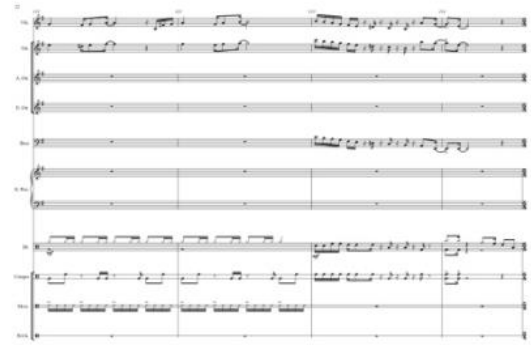

Gambar 43. Subbagian n.2

Subbagian $n$ pada lagu "Turning Point" diatas terdiri dari 8 birama serta tanda birama 4/4. Pada birama 117 sampai 124 merupakan disolusi dari tema pertama yang keempat lagu ini karena mengulang disolusi tema awal dan menambahkan beberapa variasi melodi serta ada setelah disolusi yang ketiga antara birama 37 sampai birama 44. Memiliki progresi akord secara berturut-turut EmF\#dim-Am-Em-C-D-Bm-Em-Am-B-Em. Pada birama 120 sampai birama 121 instrumen violin memainkan melodic variation and fake dari disolusi tema utama dengan menambahkan 3 nada sebelum ketukan pertama berbeda dengan awalnya. Hal tersebut dapat dilihat pada notasi berikut.

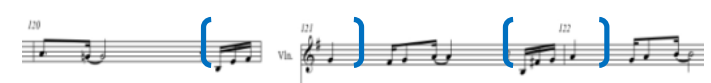

Gambar 44. Subbagian $n$ : melodic variation and fake Pada instrumen gitar, melakukan filler diakhir frase (tail) terhadap melodi yang dimainkan violin sebagai melodi tambahan untuk mengisi kekosongan di akhir frase. Hal tersebut dapat dilihat pada notasi berikut.

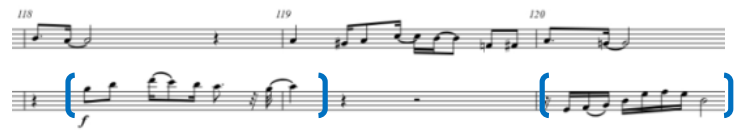

Gambar 45. Subbagian n : filler (tail)

Pada birama 124 ketukan ketiga terjadi retransisi antisipatif atau anticipatory transition pada instrumen drum seperti pada birama 29, 44, dan 67 dengan pola ritmik yang sama.

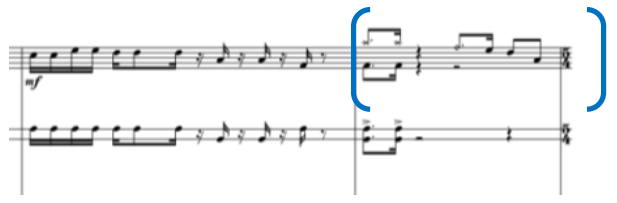

Gambar 46. Subbagian $n$ : atau anticipatory transition Subbagian o

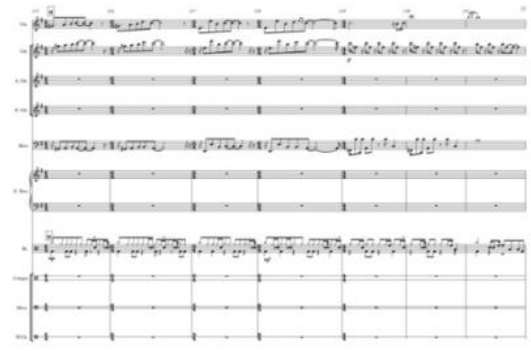

Gambar 47. Subbagian o

Subbagian o pada lagu "Turning Point" diatas terdiri dari 7 birama serta tanda birama secara berturut-turut 5/4,6/4, 5/4,6/4, kemudian kembali ke 4/4. Pada birama 125 sampai birama 131 merupakan merupakan repetisi tema kedua dari lagu ini karena mengulang subbagian e dan subbagian $h$, tetapi selalu memiliki transisi yang berbeda diakhir pada ritmis drum. Memiliki progresi akord secara berturut-turut E-Am sebanyak empat kali kemudian F dan B. Sama seperti subbagian e dan subbagian h, instrumen gitar 
dan bass melakukan rythmic variation and fake dengan memberi selisih 1/32 ketuk lebih lambat dari violin sebagai pemegang melodi utama. Instrumen bass didalamnya melakukan counter melodi terhadap violin dan gitar yang pola melodinya sama sebagai pengisi garis harmoni melodi utama tetapi tetap mengikuti selisih ketukan yang terjadi di instrumen gitar hingga birama 129 sebelum terjadi perpindahan tanda birama menjadi 4/4 .

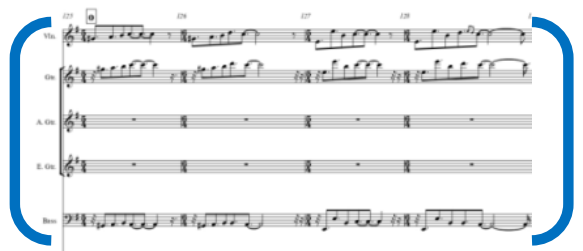

Gambar 48. Subbagian o : rythmic variation and fake

Pada instrumen drum, birama 131 merupakan transisi singkat atau bridge yang berbeda dari sebelumnya sebagai penghubung antara repetisi tema kedua dengan disolusi tema utama atau koda selanjutnya. Hal tersebut dapat dilihat pada notasi berikut.

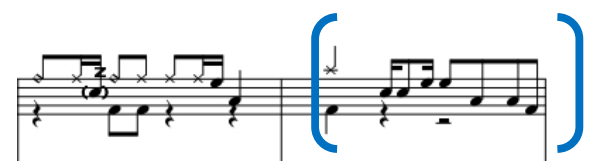

Gambar 49. Subbagian o : transisi singkat atau bridge Subbagian p

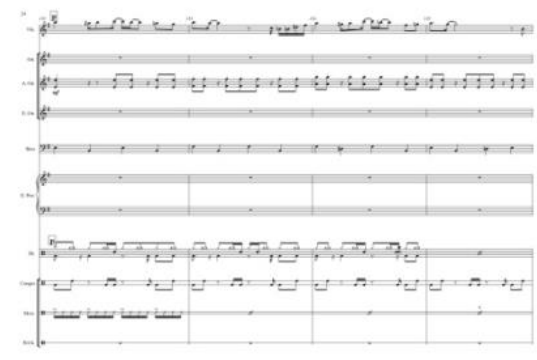

Gambar 50. Subbagian p.1

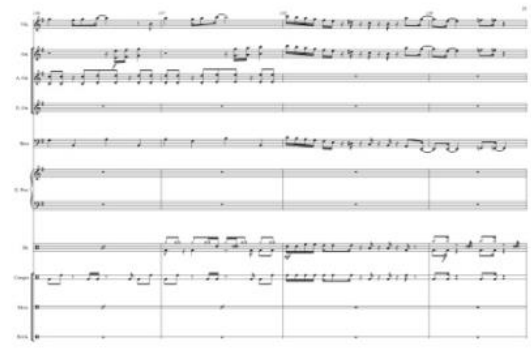

Gambar 51. Subbagian p.2

Subbagian $\mathrm{p}$ pada lagu "Turning Point" diatas terdiri dari 8 birama serta tanda birama 4/4. Pada birama 132 sampai 139 merupakan disolusi dari tema pertama yang kelima lagu ini karena mengulang disolusi tema awal dan menambahkan beberapa variasi melodi serta ada setelah disolusi yang keempat antara birama 117 sampai birama 124. Juga menjadi serangkaian koda sebagai penutup lagu "Turning Point". Memiliki progresi akord secara berturut-turut Em-F\#dim-Am-Em-C-DBm-Em-Am-B-Em-F. Melodic variation and fake terjadi pada birama antara birama 135 sampai birama 137 karena berbeda dengan disolusi tema utama. Hal tersebut dapat dilihat pada notasi berikut.

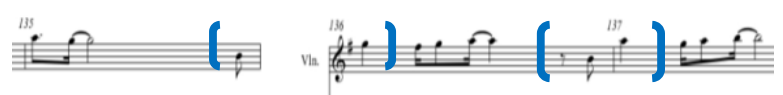

Gambar 52. Subbagian $\mathrm{p}$ : melodic variation and fake Pada instrumen gitar, melakukan filler diakhir frase (tail) pada birama antara 136 sampai birama 137 terhadap melodi yang dimainkan violin sebagai melodi tambahan untuk mengisi kekosongan di akhir frase. Hal tersebut dapat dilihat pada notasi berikut.

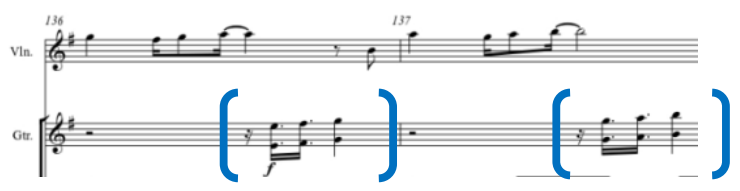

Gambar 53. Subbagian $\mathrm{p}$ : filler (tail)

Terjadi transisi singkat atau bridge pada ketukan ketiga birama 139 menandakan akan masuk koda tanpa pergantian tanda birama. Semua instrumen memainkan pola ritmis melodis yang sama baik violin sebagai instrumen utama, gitar, bass, diikuti dengan kesamaan ritmis pula antara drum, dan congas. Hal tersebut dapat dilihat pada notasi berikut.

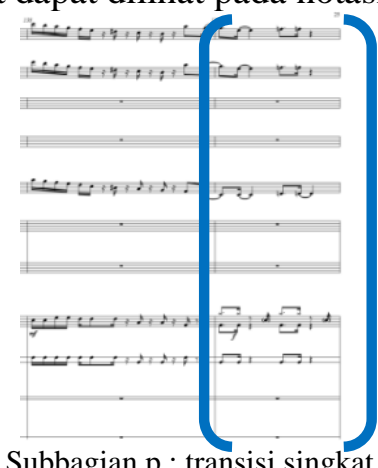

Gambar 54. Subbagian $p$ : transisi singkat atau bridge 


\section{Subbagian q}

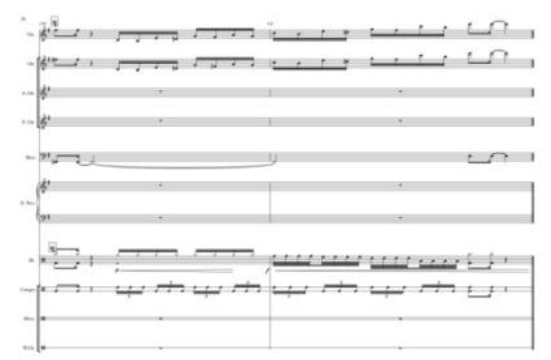

Gambar 55. Subbagian $q$

Subbagian q pada lagu "Turning Point" diatas terdiri dari 2 birama serta tanda birama 4/4. Pada birama 140 sampai 141 merupakan postlude dari lagu ini karena terletak di akhir lagu diikuti oleh koda sebelumnya. Memiliki progresi akord secara berturut-turut F\#dim-Em. Bass melakukan counter melodi dengan violin dan gitar yang memainkan melodi yang sama supaya memperkuat jalannya harmoni yang ada begitupun juga dengan drum dan congas yang mengikuti tetapi tidak menyamai alur ritmis bass sebagai pelengkap koda. Hal tersebut dapat dilihat pada notasi berikut.

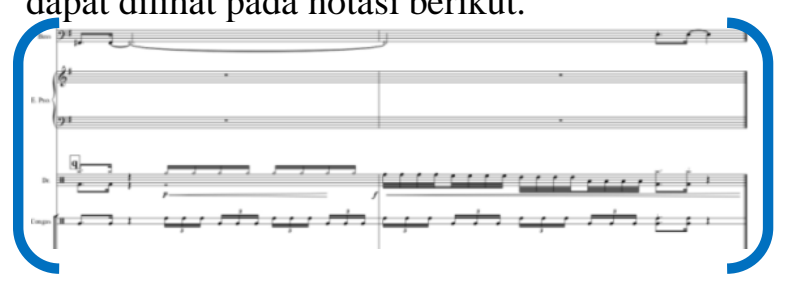

Gambar 56. Subbagian q : postlude

Gaya permainan

\section{Gaya (Style) Didiet Violin}

Gaya (style) seorang Didiet Violin yang terdapat pada lagu "Turning Point" ini merupakan gaya pembawaan yang telah dipelajari seiring dengan proses berlatih hingga terciptanya lagu. Didiet violin tidak hanya mempelajari satu atau dua gaya bermain untuk sebuah lagu, tetapi apa yang dipelajarinya merupakan kesukaan atau ketertarikan pada gaya tersebut. Berdasarkan lagu-lagu yang telah diciptakannya di album "Didiet \& Violin", lagu yang berjudul "Turning Point" ditentukan gaya nya setelah menentukan genre-nya. Gaya (style) yang terdapat didalam lagu "Turning Point" merupakan Klasik, dan Jazz. Gaya klasik bisa dilihat dari beberapa teknik permainan didalam lagu klasik pada umumnya yang akan dijelaskan pada teknik permainan nanti. Gaya jazz dalam lagu "Turning Point" dapat dilihat dari pemilihan nada, serta pada progres akord yang bisa dilihat pada penjelasan sebelumya pada bagian aransemen lagu ini sehingga tidak hanya tergantung pada patokan sebuah genre yang berarti gaya tersebut berdiri sendiri sebagai pembawaan seorang Didiet Violin.

\section{Teknik permainan Didiet Violin dalam lagu "Turning Point"}

Ada beberapa teknik yang terdapat pada lagu turning point, teknik tersebut ada berdasarkan keinginan seorang Didiet Violin untuk dimasukkan kedalam lagu ini. teknikteknik yang dilakukan termasuk gaya permainan didiet violin dalam lagu "Turning Point”. Teknik permainan tersebut meliputi:

Pizzicato

Pizzicato pada lagu "Turning Point" terletak awal sebelu tema utama tepatnya di bagian introduksi. Teknik ini juga mewakili rythm Brazilian Samba yang dimainkan oleh Didiet Violin. Pada bagian pizzicato ini, Didiet memutuskan untuk membagi menjadi dua layer sebagai counter melodi agar memperindah lagu ini. Berikut bagian Pizzicato pada lagu "Turning Point".

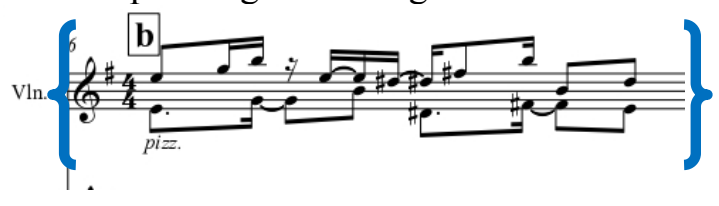

Gambar 57. Teknik Permainan Didiet : Pizzicato Staccato

Pada lagu "Turning Point" ini, teknik staccato sering digunakan oleh Didiet Violin. Teknik ini terlihat pada beberapa birama. Berikut bagian Staccato pada lagu "Turning Point"

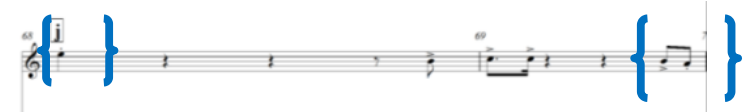

Gambar 58. Teknik Permainan Didiet : Staccato 1

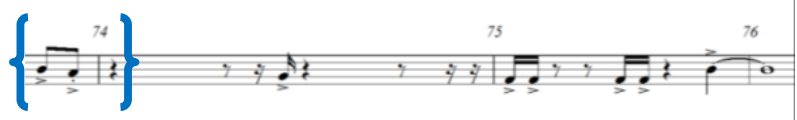

Gambar 59. Teknik Permainan Didiet : Staccato 2 Sautille

Teknik Sautille digunakan pada lagu "Turning Point". Terlihat pada setiap nada yang memiliki harga nada 1/16 secara runtut. Teknik ini terjadi berdasarkan tempo 115 yang digunakan dalam lagu ini dipadukan dengan harga nada yang demikian rapat sehingga jika tidak menggunakan teknik ini, seorang pemain biola akan kesulitan menjangkau not secara 
detil. Berikut bagian Sautille pada lagu "Turning Point".

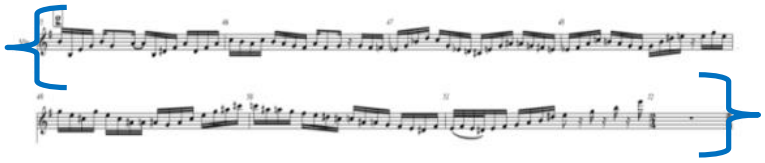

Gambar 60. Teknik Permainan Didiet : Sautille

\section{Glissando}

Pada lagu ini, Didiet Violin memberikan sentuhan glissando terhadap lagu "Turning Point". Teknik glissando tersebut tidak dimasukkan kedalam notasi, tetapi diinterpretasikan dengan sendirinya sebagai bagian dari gaya seorang Didiet Violin. Dimainkan diawal nada dan beberapa bagian yang sudah direncanakan sebelumnya. Berikut bagian Glissando pada lagu "Turning Point".

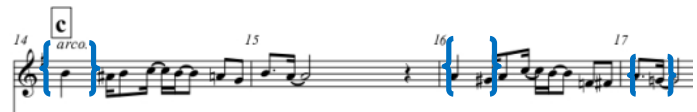

Gambar 61. Teknik Permainan Didiet : glissando Legato

Teknik legato juga digunakan didalam lagu "Turning Point" ini. pada lagu tersebut. Didiet Violin menggunakan teknik legato sebagai hiasan saja. Pada penerapannya legato yang digunakan ada yang bertujuan sebagai penghubung antara dua nada atau lebih (tie) atau menghubungkan beberapa nada yang berbeda (slur). Berikut bagian Legato pada lagu "Turning Point".
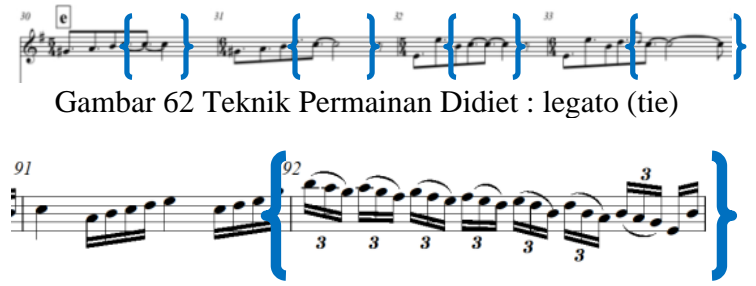

Gambar 63 Teknik Permainan Didiet : legato (slur)

\section{Doublestop}

Teknik doublestop juga digunakan Didiet Violin pada lagu "Turning Point" ini. dengan menggunakan dua jari untuk mendapatkan dua suara yang berbeda pada instrumen violin yang digunakannya. Berikut bagian Doublestop pada lagu "Turning Point".

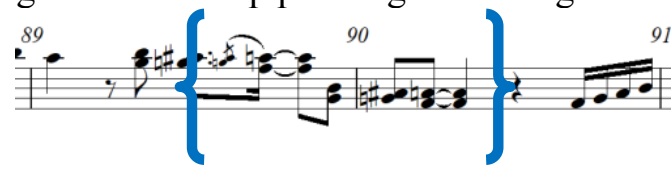

Gambar 64. Teknik Permainan Didiet : doublestop Genre yang terdapat pada lagu "Turning Point"

Pada lagu "Turning Point", terdapat sebuah konsep Aransemen lagu oleh Didiet Violin dengan menentukan sebuah genre lagu pada awalnya. Didiet mempertimbangkan beberapa genre yang cocok untuk lagu "Turning Point" berdasarkan genre yang telah digarap di lagu sebelumya pada album "Didiet \& Violin" yakni genre Pop, Jazz, dan Rock. Pada lagu "Turning Point" sendiri, genre yang diterapkan merupakan genre Latin dengan Samba pattern, tepatnya Brazilian Samba. Penentuan genre tersebut bertujuan sebagai identitas diri seorang Didiet Violin bahwa seorang musisi harus bisa ditempatkan dimana saja dengan genre dan gaya permainan apapun. PENUTUP

Lagu "Turning Point" merupakan aransemen instrumen dengan struktur lagu satu bagian yang terdiri dari 141 birama, dimainkan dengan 10 instrumen masing-masing violin, 3 macam gitar, bass, piano, drum, serta perkusi (congas, maraccas, windchimes), Lagu "Turning Point" merupakan lagu dengan beberapa subbagian, diantara lain, Introduksi, Transisi, Tema 1, Disolusi Tema 1, Retransisi, Tema 2, Disolusi Tema 2 , Interlude, Repetisi Tema 2, Kodeta Melodis, Koda, dan Postlude, Pada Introduksi, terdapat melodic variation and fake, kemudian counter melody diakhiri dengan transisi sebagai penghubung kebagian selanjutnya, Terdapat tujuh transisi berbeda yang ada pada setiap perpindahan menuju subbagian baru, kemudian empat kali retransisi hadir untuk mengulagi bagian transisi yang sama telah hadir sebelumnya, Disolusi bertujuan sebagai pengulang dari Tema 1 dan Tema 2 dengan menambahkan melodic variation and fake sehingga tema tersebut terjadi pengembangan pada bagian melodi, Interlude pada lagu "Turning Point" terjadi dua kali, pertama terjadi antara disolusi tema 1 dengan repetisi tema 2 dimainkan oleh violin, gitar, dan bass sebanyak 7 birama secara bersamaan kemudian terjadi antara disolusi tema 1 yang kedua dengan kodeta melodis dimainkan bergantian oleh congas 8 birama, violin 16 birama, gitar 16 birama, Kodeta melodis terdapat pada subbagian M, instrumen piano melakukan filler like obbligato untuk mengisi kekosongan pada melodi utama, diikuti dengan drum dan congas yang memainkan sixtuplet secara bersamaan dengan piano, Koda merupakan bagian dari disolusi tema 1. Pada instrumen gitar melakukan filler terhadap melodi violin dan kemudian diakhiri dengan transisi, Postlude berada pada subbagian q, Memiliki progresi 
akord secara berturut-turut F\#dim-Em. Bass melakukan counter melody dengan violin dan gitar yang memainkan melodi yang sama supaya memperkuat jalannya harmoni, Didiet Violin menerapkan Gaya (style) Klasik, dan Jazz didalam lagu "Turning Point", Didiet Violin dalam lagu "Turning Point" menggunakan teknik permainan pizzicato, staccato, sautille, glissando, legato, dan doublestop untuk menunjang gaya permainannya, Genre yang digunakan pada lagu "Turning Point" merupakan genre Latin dengan Samba pattern, tepatnya Brazilian Samba.

\section{DAFTAR PUSTAKA}

Alwi, H. (2007). Kamus besar bahasa Indonesia. Jakarta: balai pustaka.

Banoe, P. (2003). Kamus Musik. Kanisius

Bruce, B., \& Saker, M. N. (2003). Music: In Theory and Practice, Cilt I.

Duarte, J. (1980). Melody and Harmony for Guitarists.

Harrison, W. (2005). The Rockmaster System: Relating Ongoing Chords to the Keyboard. New York: Dellwin Publishing Co.

Honegger, M., \& Massenkeil, G. (1987). Das Große Musiklexikon.

Jamalus, D. (1988). Pengajaran Musik Melalui Pengalaman Musik. Jakarta: Departemen Pendidikan dan Kebudayaan.

Kamien, R., \& Kamien, A. (1988). Music: an appreciation. New York: McGrawHill.

Karolyi, O. (1965). Introducing music. Penguin (Non-Classic)
Karl-Edmund Prier, S. J. (2008). Sejarah Musik Jilid 1. Yogyakarta: Pusat Musik (Iturgi 1991), 52.

Kawakami, G. (1975). Arranging Popular Music: A Practical Guide. Yamaha Music Foundation.

Kustap, M. (2008). Seni Musik Klasik Jilid 1 untuk SMK. Jakarta: Direktorat .

Monath, N. (1984). How to Play Popular Piano in 10 Easy Lessons. New York: Fireside Books.

Prier, K. E., \& Edmund, K. (1996). Ilmu bentuk musik. Yogyakarta: Pusat Musik Liturgi.

Sanjaya, W. (2013). Penelitian Pendidikan jenis, metode dan prosedur. Jakarta: Kencana.

Schoenberg, A. (1983). Structural functions of harmony, ed. Leonard Stein (London, 1969), 7-9.

Sugiyono, P. (2005). Memahami penelitian kualitatif. Bandung: Alfabeta .

Sugiyono, P. (2011). Metodologi penelitian kuantitatif kualitatif dan $R \& D$. Alpabeta, Bandung .

Sugiyono, S. (2015). Metode penelitian pendidikan pendekatan kuantitatif, dan $R \& D$. Alfabeta Bandung.

Surmani, A., Surmani, K. F., \& Manus, M. (2004). Alfred's Essentials of Music Theory: A Complete Self-study Course for All Musicians. Alfred Music Publishing.

Syafiq, M. (2003). Ensiklopedia Musik Klasik. Adicita. 